\title{
PERLINDUNGAN HUKUM TERHADAP KONSUMEN PRODUK PANGAN OLAHAN YANG MENGANDUNG BAHAN REKAYASA GENETIK
}

\author{
Suyadi \\ Fakultas Hukum Universitas Jenderal Soedirman Purwokerto, Jawa Tengah
}

\begin{abstract}
Obligation to write a description of genetically engineered food manunjukkan does not mean that the product of genetic engineering that use materials are not safe, but the subscription is more information, because basically the food products that have been circulating in the market is a product that is safe for consumption means that products are free from material substances that are harmful to humans and how the processing should ensure the safety of the product, therefore the information in the form of inclusion of the words "Food Genetic Engineering" is intended to meet the consumers' right to choose the right form of goods or services to be consumed, which in this case is part of legal protection for consumers.
\end{abstract}

Keywords: Protection Law, Consumer Protection Act, Genetic Engineering of Food, Consumer, Entrepreneur

\begin{abstract}
Abstrak
Kewajiban mencantuman keterangan tentang pangan rekayasa genetika tidak berarti manunjukkan bahwa produk yang memakai bahan rekayasa genetika tersebut tidak aman, akan tetapi pencantuman tersebut lebih bersifat informasi, sebab pada dasarnya produk pangan yang telah beredar dipasaran merupakan produk yang aman untuk dikonsumsi artinya produk tersebut bebas dari bahan-bahan yang berbahaya bagi manusia serta cara pengolahannya harus menjamin keamanan produk tersebut, oleh karena itu informasi berupa pencantuman tulisan "Pangan Rekayasa Genetika" lebih ditujukan untuk memenuhi hak konsumen berupa hak untuk memilih barang atau jasa yang akan dikonsumsinya, yang dalam hal ini merupakan bagian dari perlindungan hukum bagi konsumen.
\end{abstract}

Kata Kunci: Perlindungan Hukum, Undang-Undang Perlindungan Konsumen, Pangan Rekayasa Genetika, Konsumen, Pengusaha

\section{Pendahuluan}

Perlindungan konsumen merupakan hal yang masih relatif baru di Indonesia, tetapi masih banyak kasus konsumen yang dirugikan tetapi konsumen merasa kesulitan untuk menuntut ganti rugi, bahkan konsumen terkesan sangat lemah kedudukannya di hadapan pelaku usaha, karena yang menjadi kebiasaan di Indonesia adalah asas "take it or leave it", konsumen di Indonesia hanya dijadikan objek aktivitas bisnis oleh para pelaku usaha. Dikaitkan dengan kemajuan teknologi pun seringkali konsumen tidak mengetahui apa yang telah diterapkan oleh para pelaku usaha dalam produknya.

Lahirnya undang-undang Nomor 8 Tahun 1999 tentang Perlindungan Konsumen pada tanggal 20 April 1999 diharapkan dapat menciptakan kegiatan usaha perdagangan yang fair tidak hanya bagi kalangan pelaku usaha, melainkan secara langsung untuk kepentingan konsumen, baik selaku pengguna, pemanfaat maupun selaku pemakai barang dan/atau jasa yang ditawarkan oleh pelaku usaha. ${ }^{1}$

Penggunaan teknologi dalam bidag usaha produksi tidak lain merupakan upaya pelaku usaha untuk meningkatkan mutu serta hasil produksinya. Salah satu teknologi yang digunakan oleh pelaku usaha yaitu teknologi rekayasa genetika, yaitu teknologi utak-atik gen dari suatu tanaman atau hewan dimana gen dari

Gunawan Wijaya dan Ahmad Yani, 2003. Hukum Tentang Perlindungan Konsumen. Jakarta: PT. Gramedia Pustaka Utama, hlm. ix 
anaman atau hewan tersebut dimiodifikasi atau disisipi dengan gen dari organisme lain yang sejenis atau berbeda sama sekali untuk mendapatkan tanaman atau hewan "baru" yang mempunyai keunggulan dan diminimalisir keburukannya sehingga teknologi ini sebenarnya berbeda dengan teknik kawin silang, okulasi atau teknik lain yang sejenis, dimana teknologi ini banyak diaplikasikan dalam bidang industri yang bergerak dibidang pembudidayaan tanaman produksi serta industri pengolahan pangan.

Pesatnya perkembanagan industri pengolahan pangan tidak terlepas dari laju pertumbuhan manusia yang sangat pesat di seluruh dunia umumnya dan Inonesia khususnya serta perubahan pola konsumsi yang cenderung instan.

Peningkatan jumlah produksi merupakan upaya pelaku usaha untuk memenuhi peningkatan jumlah permintaan, tetapi terkadang upaya meningkatkan jumlah produksi terhambat dengan terbatasnya jumlah bahan baku yang tersedia terutama bahan baku dari alam, karena mengandalkan hasil alam yang tidak pasti maka banyak industri pangan yang beralih kepada tanaman hasil teknologi rekayasa genetika yang memang direkayasa agar genjah/ ntingkat produksi tinggi lebih dari tanaman biasa, disamping itu biaya yang murah akan sangat berpengruh dalam perolehan keuntungan.

Awal adanya teknologi ini sebenarnya disebabkan karena jumlah pangan alami mulai tidak sebanding dengan jumlah populasi manusia yang terus bertambah, ditambah dengan berkurangnya lahan-lahan pertanian, merebaknya hama penyakit tanaman, perubahan iklim yang tidak menentu yang berdampak kepaa tidak maksimalnya tanaman pangan alami dalam berproduksi disamping biaya tinggi dalam pembudidayaannya. Maka para ahli tanaman mencoba untuk mendapatkan tanaman "super" yang bisa mengatasi berbagai masalah tersebut, namun dalam perkembangannya tanaman hasil rekayasa genetika ini menimbulkan perdebatan tentang tingkat keamanannya jika dikonsumsi manusia, sebagian pihak menyatakan bahaya, sebagian lainnya menyatakan aman, dalam hal ini Yayasan Lembaga Konsumen Indonesia (YLKI) mengacu kepada pendapat pertama.

Pada Desember 2001-Januari 2002 YLKI melakukan penelitian kualitatif kandungan rekayasa genetika dalam produk pangan, hasilnya beberapa produk makanan turunan kedelai, jagung dan kentang terdeteksi mengandung bahan rekayasa genetika atau transgenic dan beberapa produk merupakan produk yang telah akrab dikonsumsi. Seperti terungkap dalam Fokus Group Diskusi Hasil Penelitian Pangan Rekayasa Genetika, di Jakarta. ${ }^{2}$

Menurut Hadi Evianto, kerugian yang mendapat sorotan tajam (dalam bidang perlindungan konsumen) adalah kerugian yang membahayakan kesehatan dan/atau jiwa konsumen. Sedangkan perwujudan perlindungan konsumen sangat jelas terlihat dalam bidang produksi pangan, karena pangan berkaitan langsung dengan keamanan dan keselamatan jiwa dan kesehatan manusia. ${ }^{3}$

Berdasarkan hal di atas, konsumen mempunyai hak untuk mendapatkan keamanan dan keselamatan dalam mengkonsumsi pangan umumnya serta pangan olahan yang mengandung bahan rekayasa genetika khususnya dan mendapatkan perlindungan hukum apabila terjadi kerugian konsumen akibat mengkonsumsi pangan yang mengandung bahan rekayasa genetika. Berdasarkan uraian latar belakang tersebut di atas, maka artikel ini akan membahas perlindungan hukum terhadap konsumen produk pangan olahan yang mengandung bahan-bahan rekayasa genetika.

\section{Pembahasan}

Kebutuhan akan pangan merupakan kebutuhan dasar bagi manusia. Kebutuhan ini berkaitan erat dengan kesehatan dan keselamatan manusia yang mengkonsumsinya. Oleh karena itu tanggung jawab pelaku usaha di bidang

\footnotetext{
A Hery Suyono, 2001."Otak -Atik Gen Melahirkan 'Monster'” dalam Intisari. Edisi Mei 2001 Nomor 454 Tahun XXXVII.

3 Hadi Evianto, 1986, Hukum Perlindungan Konsumen Bukanlah Sekedar Keinginan Melainkan Suatu Kebutuhan, dalam Hukum Dan Pembangunan, Nomor 6 Tahun ke - XVI, Desember 1986, hlm. 582-599
} 
pangan dan pengolahan pangan merupakan tanggung jawab yang besar dan berat sehingga pelaku usaha harus bisa menjamin keamanan produknya. Menurut Pasal 1 angka 1 UndangUndang Nomor 8 Tahun 1999 tentang Perlindungan Konsumen

Perlindungan konsumen adalah segala upaya yang menjamin adanya kepastian hukum untuk memberi perlindungan kepada konsumen.

\section{Shidarta menyatakan:}

"Perlindungan konsumen pada dasarnya merupakan bagian dari hukum konsumen yang memuat asas-asas atau kaidahkaidah yang bersifat mengatur dan juga mempunyai sifat melindungi konsumen beserta hak-haknya". ${ }^{4}$

Salah satu bentuk upaya tersebut yaitu dikeluarkannya peraturan yang memuat persyaratan yang harus dipenuhi oleh pelaku usaha dalam melakukan kegiatan produksi sehingga barang atau jasa yang dihasilkannya menjadi aman untuk dikonsumsi. Pemenuhan syarat-syarat oleh pelaku usaha adalah wajib, sehingga jika pelaku usaha tidak melaksanakan kewajibannya tersebut atau hanya melaksanakan sebagiannya saja berarti dianggap telah melakukan pelanggaran, dan juga resiko yang akan timbul yaitu barang atau jasa menjadi tidak aman untuk dikonsumsi karena tidak tercapainya baku mutu yang telah ditetapkan.

Persyaratan-persyaratan yang wajib dipenuhi oleh pelaku usaha dalam berproduksi dari tahap pra produksi sampai tahap pascaproduksi secara umum telah mencakup seluruh bentuk perlindungan terhadap konsumen. Dalam bidang pengolahan pangan seluruh hak konsumen yang disebutka dalam Pasal 4 Undang-Undang Nomor 8 Tahun 1999 tentang Perlindungan Konsumen telah tercakup, tetapi hal ini tidak hanya berlaku pada bidang pengolahan pangan karena secara umum perlindungan terhadap konsumen mencakup seluruh bidang produksi.

Perlindungan konsumen dimaksudkan sebagai perlindungan terhadap hak-hak konsu-

4 Shidarta, 2000, Hukum Perlindungan Konsumen, Jakarta: P.T Grasindo, hlm 14 men. Hak-hak konsumen yang perlu dilindungi menurut Pasal 4 Undang-Undang Nomor 8 Tahun 1999 tentang Perlindungan Konsumen meliputi:

a. Hak atas kenyamanan, keamanan, dan keselamatan dalam mengkonsumsi barang dan/ atau jasa;

b. Hak untuk memilih barng dan/atau jasa serta mendapatkan barang dan/atau jasa tersebut sesuai dengan nilai tukar dan kondisi serta jamina yang dijanjikan;

c. Hak atas informasi yang benar, jelas, dan jujur mengenai kondisi dan jaminan barang dan/atau jasa;

d. Hak untuk didengar pendapat dan kluhannya atas barang dan/atau jasa yang digunakan;

e. Hak untuk mendapatkan advokasi, pelindungan, dan upaya penyelesaian sengketa perlindungan konsumen secara patut;

f. Hak untuk mendapat pembinaan dan pendidikan konsumen;

g. Hak untuk diperlakukan atau dilayani secara benar dan jujur serta tidak diskriminatif;

h. Hak untuk mendapatkan kompensasi, ganti rugi dan/atau penggantian, apabila barang dan/atau jasa yang diterima tidak sesuai dengan perjanjian atau tidak sebagaiman mestinya;

i. Hak-hak yang diatur dalam ketentuan perudnang-undangan.

Sedangkan hak-hak konsumen menurut John F. Kennedy tediri dari:

1. hak memperoleh keamanan (the right to safety);

2. hak memilih (the right to choose);

3. hak mendapat informasi (the right to be inormed);

4. hak untuk didengar (the right to be hear). ${ }^{5}$

Dari penjabaran hak-hak konsumen menurut UUPK serta menurut John F. Kennedy hak konsumen yang paling penting umtuk mendapat perlindungan yaitu hak mendapatkan keamanan dan keselamatan.

Pasal 13 Undang-undang nomor 7 tahun 1996 tentang Pangan menyatakan:

http://edukasi.kompasiana.com/2010/01/29/sudah-saatnya-hak-konsumen-adalah-merupakan-hak-fundamental/ diakses tanggal 5 Mei 2010 pukul 19.15 WIB 
1) Setiap orang yang memproduksi pangan atau menggunakan bahan baku, bahan tambahan pangan, dan atau bahan bantu lain dalam kegiatan atau proses produksi pangan yang dihasilkan dari proses rekayasa genetika wajib telebih dahulu memeriksakan keamanan pangan bagi kesehatan manusia sebelum diedarkan.

2) Pemerintah menetapkan persyaratan dan prinsip penelitian, pengembangan, dan pemanfaatan metode rekayasa genetika dalam kegiatan atau proses produksi pangan, serta menetaptkan persyaratan bagi pengujian pangan yang dihasilkan dari proses rekayasa genetika.

Penjelasan Pasal 13 ayat (2) menyatakan bahwa prinsip penelitian dalam ruang lingkup rekayasa genetika merupakan hal yang sangat spesifik dan mempunyai dampak terhadap keselamatan manusia, etika, moral, dan keyakinan masyarakat sehingga perlu pengaturan oleh pemerintah untuk mencegah terjadinya pelanggaran yang mungkin merugikan masyarakat.

Tentang keamanan pangan rekayasa genetika apabila dikaitkan dengan Pasal 4 huruf a Undang-Undang Nomor 8 Tahun 1999 tentang Perlindungan Konsumen, pasal 13 ayat (2) Undang-Undang Nomor 7 tahun 1996 tentang Pangan beserta penjelasannya, serta pendapat John F. Kennedy, maka dapat dideskripsikan bahwa konsumen dalam penggunaan produk pangan olahan yang mengandung rekayasa genetika telah dilindungi hak-haknya dalam hal kenyamanan, keamanan, dan keselamatan.

Upaya perlindungan terhadap konsumen tidak akan bisa berjalan tanpa adanya pengawasan baik dari oleh pemerintah, masyarakat, maupun oleh lembaga perlindungan konsumen swadaya masyarakat. Mengenai ketentuan tentang pengawasan diatur dalam Pasal 30 ayat (1) dan ayat (2) Undang-Undang Nomor 8 Tahun 1999 tentang Perlindungan Konsumen. takan;

Ketentuan pasal 30 ayat (1) UUPK menya-

Pengawasan terhadap penyelenggaraan perlindungan konsumen serta penerapan ketentuan peraturan perundang-undangannya diselenggarakan oleh pemerintah, masyarakat, dan lembaga perlindungan konsumen swadaya masyarakat.

Pasal 30 ayat (2) menyatakan bahwa pengawasan oleh pemerintah sebagaimana dimaksud pada ayat (1) dilaksanakan oleh menteri dan/atau menteri teknis yang terkait.

Lebih jelasnya bentuk pengawasan tersebut diatur dalam Pasal 8 Peraturan Pemerintah Nomor 58 Tahun 2001, Tentang Pembinaan dan Pengawasan Penyelenggaraan Perlindungan Konsumen yang menegaskan bahwa:

(1) Pengawasan oleh pemerintah dilakukan terhadap pelaku usaha dalam memenuhi standar mutu produksi barang dan/atau jasa, pencantuman label dan klausula baku, serta pelayanan purna jual yang dimaksud, pelayanan yan dilakuakan oleh pelaku usaha terhadap konsumen, misalnya tersedianya suku cadang dan jaminan atau garansi.

(2) Pengawasan sebagaimana dimaksud dalam ayat (1) dilakukan dalam proses produksi, penawaran, promosi, pengiklanan, dan penjualan barang dan/atau jasa.

(3) Hasil pengawasan sebagaiman dimaksud dalam ayat (2) dapat disebarluaskan kepada masyarakat.

(4) Ketentuan mengenai tata cara pengawasan sebagaimana dimaksud dalam ayat (1) ditetapkan oleh Menteri dan atau menteri teknis terkait bersama-sama atau sendirisendiri sesuai dengan bidang tugasnya masing-masing.

Pengawasan terhadap keamanan pangan yang mengandung bahan rekayasa genetika oleh pemerintah telah dilaksanakan yaitu melalui Menteri Pertanian bekerjasama dengan Direktorat Jendral Badan Pengawasan Obat dan Makanan.

Terjaminnya keamanan suatu produk berkait erat dengan kepatuhan pelaku usaha untuk memenuhi persyaratan yang ditentukan dalam peraturanperundang-undangan. Tidak dipatuhinya persyaratan akan menimbulkan resiko timbulnya bahaya pada barang atau jasa yang dihasilkan oleh pelaku usaha. 
Kewajiban pelaku usaha seperti tertuang dalam Pasal 7 Undang-Undang Nomor 8 Tahun 1999 tentang Perlindungan Konsumen yaitu:

a. Beritikad baik dalam melakukan kegiatan usahanya;

b. Memberikan informasi yang benar, jelas, dan jujur mengenai kondisi dan jaminan barang dan/atau asa serta memberi penjelasan penggunaan, perbaikan, dan pemeliharaan;

c. Memperlakukan atau melayani konsumen secara benar dan jujur serta tidak diskriminatif;

d. Menjamin mutu barang dan/atau jasa yang diproduki dan/atau diperdagangkan berdasarkan ketentuan standar mutu barang dan/atau jasa yang berlaku;

e. Memberi keempatan kepada konsumen untuk menguji dan/atau mencoba barang dan/atau jasa tertentu serta memberi jaminan dan/atau garansi atas barang yang dibuat dan/atau diperdagangkan;

f. Memberi kompensasi, ganti rugi, dan/atau penggantian atas kerugian akibat penggunaan, pemakaian, dan pemanfaatan barang dan/atau jasa yang diperdagangkan;

g. Memberi kompensasi, ganti rugi, dan/atau penggantian apabila barang dan/atau jasa yang diterima atau dimanfaatkan tidak sesuai dengan perjanjian.

Salah satu tujuan dari perlindungan konsumen seperti tertuang dalam Pasal 3 huruf $d$ Undang-Undang Nomor 8 Tahun 1999 tentang Perlindungan Konsumen, yaitu: “menciptakan sistem perlindungan konsumen yang mengandung unsur kepastian hukum dan keterbukaan informasi serta akses untuk mendapatkan informasi".

Informasi merupakan hal yang penting bagi konsumen. Dalam suatu kemasan pangan, informasi biasanya dalam bentuk label. Menurut Pasal 30 ayat (2) Undang-undang nomor 7 tahun 1996 tentang Pangan, label sekurangkurangnya memberikan keterangan tentang:
a. Nama produk;
b. Daftar bahan yang digunakan;
c. Berat bersih atau isi bersih;

d. Nama dan alamat pihak yang memproduksi atau memasukkan pangan ke dalam wilayah Indonesia;

e. Keterangan tentang halal; dan

f. Tanggal, bulan, dan tahun kadaluwarsa.

Penggunaan bahan rekayasa genetika sebagai bahan baku atau bahan tambahan pangan wajib dicantumkan keterangan atasnya dan pencatuman ini ditempatkan pada daftar bahan yang digunakan, maksudnya ialah tulisan "PANGAN REKAYASA GENETIKA" tidak perlu dicantumkan pada produk tersebut akan tetapi cukup dengan keterangan bahwa bahan yang digunakan dalam produk tersebut merupakan rekayasa genetika. Pencantuman logo khusus pangan hasil rekayasa genetika tidak bersifat wajib dan menjadi suatu pilihan bagi pelaku usaha apakah akan mencantumkan pada produknya atau tidak.

Kewajiban mencantumkan keterangan tentang pangan rekayasa genetika tidak berarti menunjukan bahwa produk yang memakai bahan rekayasa genetika tersebut tidak aman, akan tetapi pencantuman tersebut lebih bersifat informasi, sebab pada dasarnya produk pangan yang telah beredar di pasaran merupakan produk pangan yang aman unuk dikonsumsi artinya produk tersebut bebas dari bahanbahan yang berbahaya bagi manusia serta cara pengolahannya harus menjamin keamanan produk tersebut. Oleh karena itu informasi berupa pencantuman "PANGAN REKAYASA GENETIKA" lebih ditujukan untuk memenuhi hak konsumen berupa hak untuk memilih barang atau jasa yang akan dikonsumsinya.

Konsumen dalam hal ini diberi kebebasan untuk memilih apakah konsumen akan mengkonsumsi produk pangan yang menggunakan bahan rekayasa genetika sebagai bahan bakunya ataukah konsumen akan memilih produk yang sama akan tetapi tidak menggunakan bahan rekayasa genetika dalam bahan bakunya.

Apabila dilihat dari sudut pandang keamanan pangan, kedua produk tersebut apabila telah memenuhi persyaratan keamanan pangan maka baik produk yang menggunakan bahan rekayasa eneika maupun yang tidak, keduanya layak dikonsumsi, akan tetapi hak konsumen 
untuk memilih adalah untuk melaksanakan prinsip kehati-hatian.

Menurut Gunawan Wijaya dan Ahmad Yani, informasi merupakan hal penting bagi konsumen, karena melalui informasi tersebut konsumen dapat mempergunakan hak pilihnya secara benar. Hak memilih tersebut merupakan hak dasar yang tidak dapat dihapuskan oleh siapapun juga. Dengan mempergunakan hak pilihnya tersebut, konsumen dapat menentukan cocok tidaknya barang dan/atau jasa yang ditawarkan/diperdagangkan tersebut dengan kebutuhan dari diri masing-masing konsumen. ${ }^{6}$

Dengan pencantuman label rekayasa genetika pada kemasan pangan, maka konsumen produk pangan telah diberikan dan dilindungi haknya dalam memilih dan menentukan produk yang akan dikonsumsinya, dengan memilih produk yang mengandung bahan rekayasa atau lebih memilih produk pangan yang bukan rekayasa.

Pelaku usaha wajib bertanggung jawab apabila barang atau jasa yang dihasilkannya menimbulkan kerugian, mengenai tanggung jawab pelku usaha secara umum, diatur dalam Pasal 19 ayat (1) dan ayat (2) Undang-Undang Nomor 8 Tahun 1999 tentang Perlindungan Konsumen;

(1) Pelaku usaha bertanggung jawab memberikan ganti rugi atas kerusakan, pencemaran, dan/atau kerugian konsumen akibat mengkonsumsi barang dan/atau jasa yang dihasilkan atau diperdagangkan.

(2) Ganti rugi sebagaiman dimaksud pada ayat (1) dapat berupa pengembalian uang tau penggantian barang dan/atau jasa yang sejenis atau setara nilainya, atau perawatan kesehatan dan/atau pemberian santunan yang sesuai dengan ketentuan peraturan perundang-undangan yang berlaku.

Pelaku usaha yang memanfaatkan teknologi rekayasa genetika pada umumnya dan pelaku usaha di bidang pengolahan pangan pada khususnya wajib bertanggung jawab dan memberikan ganti rugi atau kompensai sesuai de- ngan tingkat kerugian yang diderita oleh konsumen.

\section{Penutup}

Bahwa konsumen produk pangan olahan yang mengandung bahan rekayasa genetika telah dilindungi secara hukum hak-haknya sesuai dengan ketentuan Pasal 4 Undang-Undang Nomor 8 Tahun 1999 tentang Perlindungan Konsumen, yaitu:

1. Hak atas keamanan dan keselamatan, hak ini telah dipenuhi melalui Undang-Undang Nomor 7 tahun 1996 tentang Pangan, Pasal 13, Pasal 1 angka 3 dan angka 19 serta Pasal 9 Keputusan Bersama Menteri Pertanian, Menteri Kehutanan dan Perkebunan, Menteri Kesehatan, dan Menteri Negara Pangan dan Holtikultura No 998.1/Kpts/OT.210/9/99, 790.a/Kpts/IX/99, 1145A/MENKES/SKB/IX/ 1999, 015A/Meneg PHOR/09/1999 tentang Keamanan Hayati dan Keamanan Pangan Produk Pertanian Hasil Rekayasa Genetika.

2. Hak untuk memilih barang dan/atau jasa serta hak atas informasi yang benar, jelas, dan jujur, hak ini telah dipenuhi melalui Pasal 35 Peraturan Pemerintah Nomor 69 tahun 1999 tentang Label dan Iklan Pangan mengenai kewajiban bagi pencantuman label REKAYASA GENETIKA pada kemasan pangan sebab fungsi dari label tidak hanya sebagai informasi tetapi juga agar konsumen bisa menetukan pilihan untuk membeli atau pun tidak membeli, sehingga dapat dikatakan bahwa kedua hak ini saling terkait erat.

3. Hak untuk mendapatkan kompensasi, ganti rugi dan/atau penggantian, hak ini telah dipenuhi melalui Pasal 43 Keputusan Bersama Menteri Pertanian, Menteri Kehutanan dan Perkebunan, Menteri Kesehatan, dan Menteri Negara Pangan dan Holtikultura nomor 998.1/Kpts/OT.210/9/99, 790.a/Kpts/IX/99, 1145A/MENKES/SKB/IX/1999, b015A/Meneg PHOR/09/1999 tentang Keamanan Hayati dan Keamanan Pangan Produk Pertanian Hasil Rekayasa Genetika. 